\title{
EFEKTIVITAS PEMBELAJARAN BERBASIS PROYEK PRODUK VLOG PADA MATA KULIAH PENDIDIKAN PANCASILA
}

\author{
Iman Subekti \\ Program Studi PGSD, Fakultas Keguruan dan Ilmu Pendidikan \\ Universitas Kristen Petra \\ Email: imansubekti@petra.ac.id \\ Hariyanto \\ Program Studi PGSD, Fakultas Keguruan dan Ilmu Pendidikan \\ Universitas Kristen Petra \\ Email: hariyanto.mpd@petra.ac.id
}

\begin{abstract}
Abstrak
Mata kuliah Pendidikan Pancasila sampai saat ini masih dipandang sebagai mata kuliah nomor dua atau mata kuliah yang tidak terlalu penting untuk diikuti dengan sungguh-sungguh. Hal ini juga tidak lepas dari proses pembelajarannya yang masih menerapkan pembelajaran konvensional. Penelitian ini mempunyai tujuan yaitu untuk mengetahui efektivitas dari implementasi proses pembelajaran yang berbasis proyek produk vlog sebagai model pembelajaran kooperatif dalam pembelajaran mata kuliah Pendidikan Pancasila di Universitas Kristen Petra Surabaya. Penelitian ini merupakan penelitian eksperimen yang membandingkan prestasi belajar mahasiswa yang pembelajarannya menggunakan model pembelajaran proyek berbasis produk vlog dengan mahasiswa yang pembelajarannya menggunakan model konvensional. Penelitian ini memiliki dua variabel yang meliputi keterampilan dalam berproses dan prestasi belajar. Data keterampilan dalam berproses diambil melalui kegiatan pengamatan, sedangkan data prestasi belajar diambil melalui tes tertulis. Analisa data meliputi uji pengaruh (regresi linear/ANOVAb), uji ketuntasan (One Sample T Test), dan uji perbedaan (Independent Sample T Test). Hasil dari penelitian ini adalah ada pengaruh besar $(74,70 \%)$ keterampilan proses dalam penerapan model pembelajaran berbasis proyek produk vlog terhadap prestasi belajar mahasiswa, terdapat perbedaan 18,75 dari nilai rata-rata prestasi belajar kelas eksperimen $(86,13)$ dan nilai rata-rata kelas kontrol $(67,38)$. Pembelajaran berbasis proyek produk vlog lebih efektif jika dibandingkan dengan strategi pembelajaran secara konvensional dalam meningkatkan prestasi belajar mahasiswa mata kuliah Pendidikan Pancasila.
\end{abstract}

Kata Kunci: vlog, pembelajaran kooperatif, keterampilan proses 


\begin{abstract}
Students in higher education seems to think that Pendidikan Pancasila is one of unimportant courses to be taken or seriously learned. Although it serves as a mandatory course, students might perceive Pendidikan Pancasila course has a conventional approach in its learning process. This research attempts to examine the effectiveness of a Vlog Product-Based Learning project (as cooperative learning model) of the learning and teaching Pendidikan Pancasila course in Petra Christian University. The study applied the experimental research design comparing the learning outcomes of students who were taught using the vlog product-based learning model and those who were taught using the conventional model. Two variables employed in this research were students' processing skill and their achievement in Pendidikan Pancasila course. The data for students' processing skill were gathered from the observation, and students' achievement were from their written test scores. The results shows that there is a big influence $(74,70 \%)$ of skill proceed in applying the vlog product-based learning model to the learning outcome. There is a gap of 18.75 between the average of grade in experimental group (86.13) and controlled group (67.38). The vlog product-based learning model is more effective than the conventional model in improving the learning outcome of Pendidikan Pancasila course.
\end{abstract}

Key words: vlog, cooperative learning, skill proceed

\section{PENDAHULUAN}

Dalam pelaksanaan proses pembelajaran mata kuliah Pendidikan Pancasila sering dijumpai mahasiswa kurang antusias, kurang bersemangat dan pasif dalam mengikuti perkuliahan. Strategi yang sering digunakan dosen untuk membuat mahasiswa aktif adalah dengan melibatkan mahasiswa dalam diskusi, studi kasus dan presentasi mahasiswa. Namun, strategi atau cara ini belum efektif meskipun dosen telah mendorong mahasiswa untuk selalu berpartisipasi, karena sebagian besar mahasiswa yang tidak terlibat langsung dan terpaku menjadi penonton, sementara diskusi, pemecahan masalah dalam studi kasus dan presentasi dikuasai oleh beberapa mahasiswa saja.

Proses pembelajaran mata kuliah Pendidikan Pancasila perlu direncanakan dan disusun dengan baik dan tepat dengan menyesuaikan perkembangan dunia anakanak muda zaman sekarang, sehingga mahasiswa mendapat kesempatan berinteraksi dan bekerjasama secara nyata dalam proses pembelajaran serta bertanggung jawab terhadap pemahaman tentang Pendidikan Pancasila. Pengajar 
perlu menciptakan suasana belajar yang mendorong mahasiswa membangun kesadaran dirinya akan pentingnya mempelajari Pendidikan Pancasila, serta membangkitkan rasa tanggung jawab mahasiswa dalam memahami dan menghayati nilai-nilai Pendidikan Pancasila. Dengan demikian mahasiswa terdorong untuk sungguh-sungguh mengikuti mata kuliah Pendidikan Pancasila.

Di sisi lain, pengaruh globalisasi dan perkembangan teknologi komunikasi yang begitu cepat, banyak perguruan tinggi dan lembaga telah menggunakan berbagai fasilitas teknologi komunikasi untuk mendukung proses pembelajaran. Pemanfaatan teknologi komunikasi untuk keperluan pengelolaan, khususnya dalam proses pembelajaran juga telah mengalami kemajuan yang pesat. Peralatan elektronik seperti smartphone dan laptop atau komputer saat ini menjadi sarana pendukung yang sangat penting dalam proses pengajaran dan pembelajaran. Seiring kemajuan yang terdapat dalam memberikan layanan yang berpusat pada teknologi komunikasi, dosen dapat menggunakan fasilitas-fasilitas tersebut untuk keperluan pembelajaran yang membuat mahasiswa aktif dengan terlibat secara langsung.

Dosen perlu menyusun perencanaan perkuliahannya dengan baik menyesuaikan era sekarang ini sehingga dalam pembelajarannya para mahasiswa dituntut mengimplementasikan kemajuan teknologi komunikasi. Pemanfaatan teknologi komunikasi bukan hanya sekedar untuk mencari informasi atau dipergunakan hanya untuk presentasi menampilkan suatu informasi, tetapi dimanfaatkan untuk membuat atau menciptakan informasi. Realitanya, sedikit pengajar yang aware dan berpikir merasa sangat penting untuk menggunakan teknologi komunikasi untuk diterapkan dalam proses perkuliahan yang telah direncanakannya dengan melibatkan mahasiswa secara langsung. Keadaan ini kurang bisa memotivasi semangat belajar mahasiswa untuk menggunakan teknologi komunikasi smartphone dan laptop atau komputer dalam kegiatan belajarnya. Implikasinya, mahasiswa mengalami kesulitan untuk memahami setiap materi yang diajarkan oleh para dosen.

Mahasiswa di era sekarang ini diproyeksikan untuk menjadi pribadipribadi yang berkualitas pada zamannya, memiliki moral dan kepribadian yang unggul yang mampu memahami, 
menghayati dan mengamalkan nilai-nilai Pendidikan Pancasila dalam kehidupan sehari-hari. Berkaitan dengan hal tersebut, lulusan perguruan tinggi diharapkan bisa menjadi individu yang dapat mengimplementasikan nilai-nilai

Pendidikan Pancasila yang diperoleh selama kuliah dalam dunia nyata, di lingkungan keluarga, dunia kerja dan lingkungan sosial masyarakat.

Berkaitan dengan latar belakang tersebut, peneliti melihat pentingnya pembelajaran berbasis proyek produk vlog pada perkuliahan Pendidikan Pancasila dalam menunjang keberhasilan mahasiswa memahami dan memaknai nilai-nilai yang terkandung dalam Pendidikan Pancasila.

Model Pembelajaran Berbasis Proyek Produk Vlog adalah pendekatan belajar mengajar dengan cara membuat kelompok-kelompok mahasiswa berdasarkan tingkat kemampuannya ke dalam kelompok-kelompok kecil untuk kemudian kelompok tersebut berdiskusi menyusun perencanaan untuk membuat vlog pembelajaran.

Vlog berasal dari dua kata yakni 'video' dan 'blog'. Video adalah teknologi untuk menangkap, merekam, memproses, mentransmisikan dan menyusun ulang gambar bergerak (Wikipedia, 2019). Blog merupakan rekaman private secara online yang senantiasa diperbarui serta dibagikan ke orang banyak atau masyarakat luas. Jadi, Vlog adalah rekaman pribadi yang berbentuk video yang selalu di-update serta dibagikan terbuka. Lebih tepatnya, vlog tergolong dalam suatu macam aktivitas blogging dengan memanfaatkan media video yang melebihi sumber medium utama yaitu tulisan dan atau audio.

Dalam pembelajaran ini, vlog yang dibuat mahasiswa menjelaskan tentang materi ajar Pendidikan Pancasila disertai contoh-contoh yang konkrit. Mahasiswa secara berkelompok membuat vlog. Di dalam vlog, setiap anggota kelompok menjelaskan materi ajar Pendidikan Pancasila melalui video. Pembelajaran ini termasuk dalam model cooperative learning, Menurut Slavin (1995), dampak dari aktivitas kelompok pada umumnya merupakan dampak yang positif. Bukti yang terbaik, Slavin mendapatkan bahwa 72\% dari 68 penelitian memperlihatkan bahwa prestasi belajar memperoleh nilai tinggi dalam suatu kegiatan pembelajaran secara berkelompok pada kelas eksperimen dibanding kelas kontrol.

Pembelajaran Berbasis Proyek Produk Vlog termasuk Cooperative Learning yang merupakan strategi 
pembelajaran yang mendorong mahasiswa berpikir dan bertindak secara aktif menemukan sendiri pengetahuannya melalui kegiatan keterampilan proses. Mahasiswa melakukan kegiatan pembelajaran dalam kelompok kecil yang bervariasi anggota kelompoknya. Dalam aktivitasnya, masing-masing anggota kelompok saling membantu dan bekerja bersama dalam memahami dan memaknai suatu materi ajar. Selama bekerja dalam kelompok, tugas masing-masing anggota yaitu mencapai nilai ketuntasan pokok bahasan dan saling menolong anggota kelompok untuk mencapai nilai ketuntasan (Slavin, 1995:73).

Menurut Johnson \& Johnson (1993) dalam Lie (2004:18), cooperative learning didefinisikan sebagai suatu sistem belajar dalam kelompok yang tersusun rapi dan terstruktur. Struktur ini, ada 5 komponen utama yang membentuknya, yaitu positive interdependence, individual responsibility, personal interaction, collaboration skill, dan group process. Penerapan model pembelajaran kooperatif ini telah terbukti berhasil dalam meningkatkan prestasi belajar siswa.

Di sisi lain, Tapscott dalam Growing Up Digital, mahasiswa saat ini ada dalam generasi yang dikelilingi oleh medium digital (Dryden, 2001: 90). Oleh sebab itu, proses pembelajaran perlu memanfaatkan medium digital. Medium digital di sini adalah pemanfaatan smartphone dan laptop atau komputer dalam proses pembelajaran. Dengan kemajuan perkembangan perangkat dan aplikasi teknologi komunikasi yang semakin maju dapat dimanfaatkan sebagai sarana pendukung kegiatan pembelajaran.

Menurut Sutisna (2006) penggunaan teknologi berperan sebagai alat dan sekaligus guru dalam proses pembelajaran. Smartphone dan laptop/komputer dalam penerapannya dimanfaatkan untuk merekam atau membuat video, memotret obyek atau gambar, menggambar dan membuat grafik, menyajikan berbagai informasi yang bisa diulang-ulang sesuai kebutuhan dan kecepatan reaksi mahasiswa. Selain itu smartphone dan laptop/komputer dapat digunakan sebagai pendukung pembelajaran, seperti demonstrasi materi pembelajaran, bank data yang bisa dibuka dan diambil untuk pembelajaran problem solving, simulation dan role playing.

Di dalam proses penelitian ini, mahasiswa akan memanfaatkan smartphone dan laptop/komputer sebagai sarana pembelajarannya. Diharapkan 
mahasiswa dapat menyusun dimunculkan sampai dicapainya suatu pengetahuannya sendiri yaitu dengan keadaan atau capaian-capaian khusus. memproduksi materi ajarnya sendiri dalam Sedangkan keterampilan menurut Reber proses kegiatan pembelajaran Pendidikan (Syah, 2003:121) adalah suatu kompetensi Pancasila, berupa vlog.

Untuk menilai kemajuan mahasiswa dalam proses belajarnya, dapat ditentukan dengan beberapa teknik, yaitu observasi, tes tertulis dan ujian akhir. Ada tiga jenis hasil prestasi belajar berupa keterampilan dan kebiasaan, kognitif dan pemahaman, sikap dan cita-cita (Sujana, 2005:45).

Prestasi belajar adalah penguasaan materi pembelajaran yang mencakup pengetahuan dan keterampilan sesuai dengan yang dikembangkan di dalam mata kuliah, biasanya ditunjukkan melalui nilai tes berupa angka yang disajikan oleh pengajar/dosen. Sedangkan menurut Soesilo dkk (2006:4) tes hasil belajar merupakan alat ukur untuk melihat tingkat keberhasilan metode mengajar yang telah digunakan dosen dalam proses pembelajaran. Jadi hasil belajar adalah penguasaan pengetahuan, keterampilan dan kebiasaan dengan cara mengunakan observation, written test, testimony, performance test.

Menurut Syah (2003:109) proses adalah teknik-teknik tertentu yang melaluinya berbagai perubahan mengerjakan berbagai ragam perilaku yang bervariasi dan tertata dengan rapi serta sesuai dengan kondisi dalam mewujudkan tercapainya hasil tertentu. Keterampilan sebenarnya tidak hanya prilaku psikomotorik tetapi juga perwujudan dari peran mental yang bercirikan pengetahuan. Jadi keterampilan proses untuk mahasiswa selama kegiatan pembelajaran merupakan suatu kesediaan yang diperoleh dari teknikteknik pendekatan pembelajaran yang diterapkan terhadap mahasiswa sampai terwujudnya perubahan perilaku.

\section{METODE PENELITIAN}

Penelitian ini merupakan penelitian eksperimen untuk mengetahui seberapa besar pengaruh pembelajaran berbasis proyek produk vlog terhadap prestasi belajar mahasiswa, ketuntasan prestasi belajar dan perbedaan prestasi belajar mahasiswa pada pembelajaran berbasis proyek produk vlog dibandingkan dengan pembelajaran secara konvensional.

Pada kelas kontrol, kegiatan perkuliahan dilaksanakan melalui cara konvensional sehingga metode 
pembelajaran yang dilangsungkan berbeda dengan rancangan metode pembelajaran pada kelas eksperimen. Pada kelas eksperimen, penelitian bukan saja bertumpu pada capaian pembelajaran saja, melainkan lebih kepada suatu proses pembelajaran. Oleh sebab itu dalam penelitian ini akan diamati berbagai proses aktivitas dalam pembelajaran dengan menggunakan berbagai macam indikator observasi.

Berikut ini urutan aktivitas proses pembelajaran yang diterapkan pada kelas eksperimen:

1. Membentuk kelompok-kelompok mahasiswa anggotanya $3-4$ orang dengan kompetensi yang berbeda-beda.

2. Tiap kelompok mengerjakan tugasnya yaitu mempelajari semua materi mata kuliah Pendidikan Pancasila.

3. Tiap kelompok membuat resume tentang materi yang dipelajari, membuat refleksi berkaitan relevansinya dengan kehidupan sekarang dan mengungkapkan masalah yang dihadapi dalam pembelajaran.

4. Tiap kelompok diminta membuat lima buah vlog pembelajaran sesuai dengan lima pokok bahasan yang dipelajari. Dalam tiap vlog setiap anggota berbicara menjelaskan materi yang sedang dipelajari.
5. Tiap kelompok melakukan presentasi. Tiap anggota kelompok menceritakan pengalamannya masing-masing dalam proses pembuatan vlog dan menjelaskan isi dari vlog.

6. Selama proses pembelajaran dilakukan pengamatan terhadap keterampilan proses dalam pembuatan vlog sampai memaknai materi pembelajaran.

7. Kelas eksperimen dan kelas kontrol menjalani tes prestasi belajar secara bersamaan. Data yang terkumpul dianalisis.

Skema penelitian:

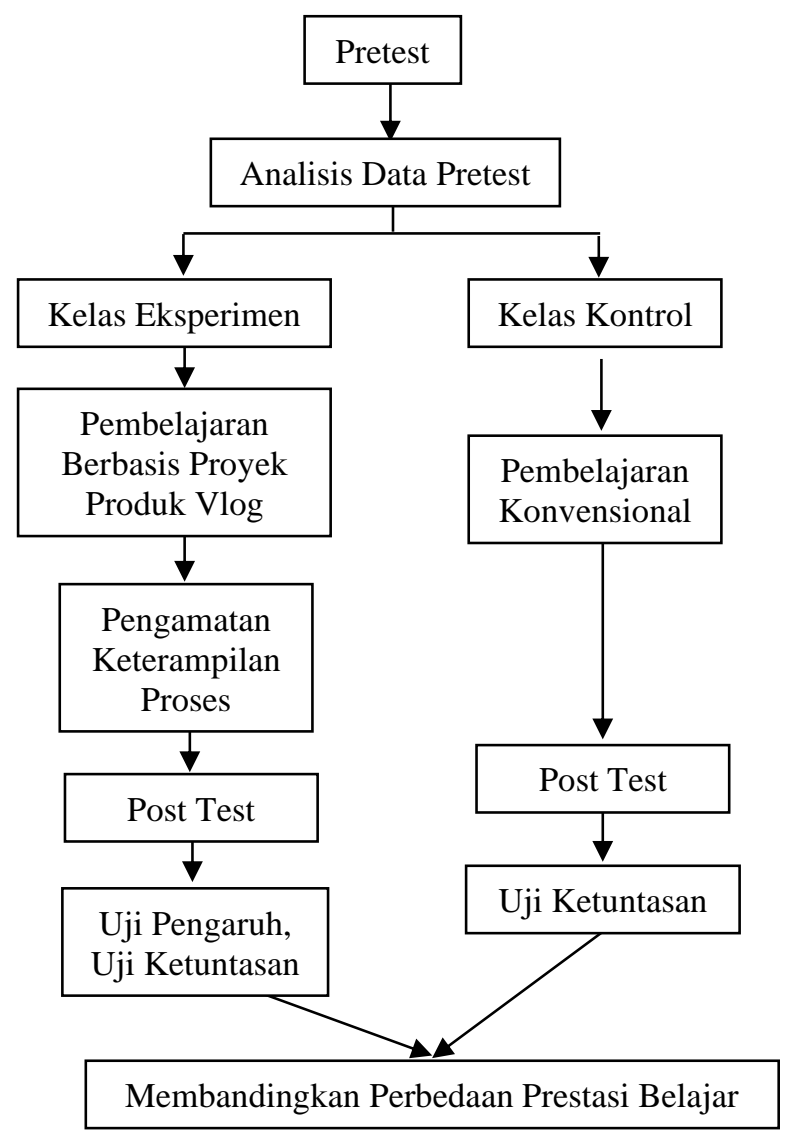

Gambar 1. Skema Penelitian 


\section{VARIABEL PENELITIAN}

Penelitian ini akan melihat pengaruh keterampilan proses terhadap prestasi belajar, ketuntasan prestasi belajar dan perbedaan prestasi belajar antara kelas eksperimen dan kelas kontrol. Variabel independen dalam penelitian adalah keterampilan proses (X) dan variabel dependen penelitian ini adalah prestasi belajar mahasiswa (Y). Perbandingan perlakuan antara kelas kontrol dan kelas eksperimen ditampilkan pada Tabel 1.

Tabel 1: Design Pretest Postest

Control (Arikunto, 2002)

\begin{tabular}{cccc}
\hline \hline Kelas & Pretest & Perlakuan & $\begin{array}{c}\text { Postest/ } \\
\text { Prestasi } \\
\text { Belajar }\end{array}$ \\
\hline \hline $\begin{array}{c}\text { Kelas } \\
\text { Kontrol } \\
\text { Kelas } \\
\text { Eksperimen }\end{array}$ & $\mathrm{P}_{1}$ & $\mathrm{~K}$ & $\mathrm{P}_{2}$ \\
\hline
\end{tabular}

Keterangan:

$\mathrm{P}_{1}$ : nilai pretest kelas control

$\mathrm{P}_{2}$ : nilai pretest kelas eksperimen

$\mathrm{K}$ : pembelajaran konvensional

$\mathrm{X}$ : keterampilan proses pada pembelajaran berbasis proyek produk vlog

$\mathrm{Y}_{1}$ : nilai post test kelas control

$\mathrm{Y}_{2}$ : nilai post test kelas eksperimen

Data dalam penelitian ini diambil dengan memakai dua cara, yaitu:

1. Observasi/pengamatan, dipakai untuk mendapatkan data keterampilan proses.

2. Tes tertulis, dipakai untuk mendapatkan data prestasi belajar mahasiswa.
Sebelum digunakan, instrumen dipastikan dulu validitas dan reliabilitasnya, sehingga instrumen merupakan instrumen terseleksi dan dapat dipakai sebagai alat pengukuran pada sampel penelitian. Variabel X (keterampilan proses) diukur dengan instrumen observasi, sedangkan variabel Y (prestasi belajar) diukur dengan menggunakan tes tertulis. Data yang didapatkan dianalisis dengan statistik deskriptif, kemudian dianalisis menggunakan analisis data kuantitatif.

Pengaruh keterampilan proses terhadap prestasi belajar dilakukan dengan Analisis Regresi. Ketuntasan prestasi belajar dilakukan dengan uji One Sample T Test. Perbedaan prestasi belajar kelompok kontrol dan kelompok eksperimen dilakukan dengan uji perbedaan (Independent Sample T Test).

\section{HASIL DAN PEMBAHASAN}

Melihat hasil uji Bartlett kesamaan varian, yang diterapkan pada nilai pretest mata kuliah Pendidikan Pancasila pada keempat kelas, diperoleh tiga kelas dengan varian sama. Dari ketiga kelas dipilih satu kelas (O) sebagai kelas kontrol dan satu kelas $(\mathrm{G})$ sebagai kelas eksperimen.

Anggota kelas eksperimen berjumlah 40 mahasiswa. Selama 
perkuliahan dengan model Pembelajaran Berbasis Proyek Produk Vlog sebagai pendekatan pembelajaran kooperatif, dilakukan observasi terhadap setiap mahasiswa untuk mendapatkan data keterampilan proses kegiatan pembelajaran yang dilaksanakan. Data keterampilan proses dilakukan analisis. Hasilnya diketahui bahwa dari 40 mahasiswa, 7 mahasiswa masuk dalam kategori sangat terampil $(17,5 \%), 24$ mahasiswa terampil (60\%), dan 9 mahasiswa cukup terampil $(22,5 \%)$.

Setelah kelas eksperimen diberi perlakuan yaitu Pembelajaran Berbasis Proyek Produk Vlog, di akhir pembahasan dilakukan tes prestasi belajar. Pada kelas kontrol kegiatan pembelajaran dilaksanakan dengan cara konvensional yaitu dengan metode presentasi dosen, berpusat pada dosen (teacher center), dan $\mathrm{di}$ bagian akhir dilakukan juga tes prestasi belajar. Hasil tes prestasi belajar kelas eksperimen dilakukan analisis guna mengetahui kenormalan dan homogenitasnya. Dari hasil analisis memperlihatkan bahwa tes prestasi belajar mahasiswa kelas eksperimen normal dan homogen. Selanjutnya dengan menggunakan analisis regresi linier, dianalisis apakah ada pengaruh keterampilan proses $(\mathrm{X})$ terhadap prestasi belajar mahasiswa (Y). Hasil pengukuran besarnya pengaruh keterampilan proses terhadap prestasi belajar dapat dilihat dari Tabel 2.

Tabel 2. Model Summary

\begin{tabular}{ccccc} 
Model & $\mathrm{R}$ & $\begin{array}{c}\mathrm{R} \\
\text { Square }\end{array}$ & $\begin{array}{c}\text { Adjusted R } \\
\text { Square }\end{array}$ & $\begin{array}{c}\text { Error of } \\
\text { the } \\
\text { Estimate }\end{array}$ \\
\hline 1 & $.865^{\mathrm{a}} !$ & .747 & .736 & 5.16539 \\
\hline a Predictors: (Constant), KeterampilanProses
\end{tabular}

Besarnya pengaruh keterampilan proses terhadap prestasi belajar dapat dilihat dari nilai $\mathrm{R}$ square adalah 0,747 yang berarti $74,70 \%$ prestasi belajar peserta didik dipengaruhi oleh faktor keterampilan proses, dan 25,30\% dipengaruhi oleh faktor lain. Dapat dikatakan keterampilan proses berpengaruh besar terhadap prestasi belajar mahasiswa.

Kemudian untuk melihat bentuk persamaan regresinya dapat dilihat dari Tabel 3.

Tabel 3. Coefficients

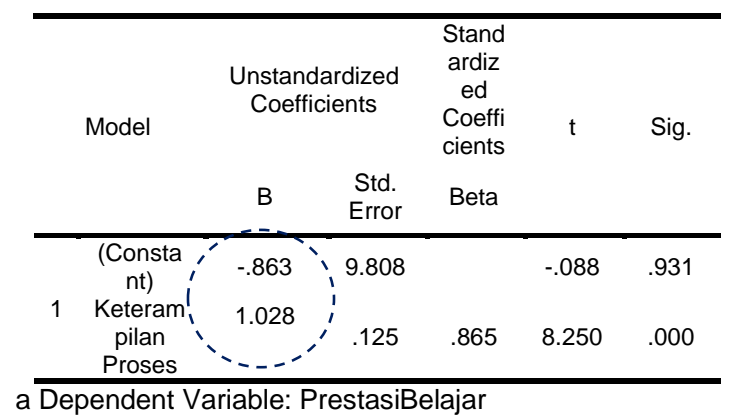

a Dependent Variable: PrestasiBelajar 
Tabel di atas menunjukkan bentuk persamaan regresinya yaitu:

$$
\hat{Y}=-0,863+1.028 X \text { dengan } X \geq 20 \text {. }
$$

Dapat dilihat pada persamaan tersebut bahwa setiap variabel keterampilan proses (variabel independen) berubah naik satu satuan maka prestasi belajar (variabel dependen) akan bertambah sebesar 1,028. Persamaan tersebut memperlihatkan suatu bentuk grafik naik yang dapat dilihat pada Gambar 2 berikut ini.

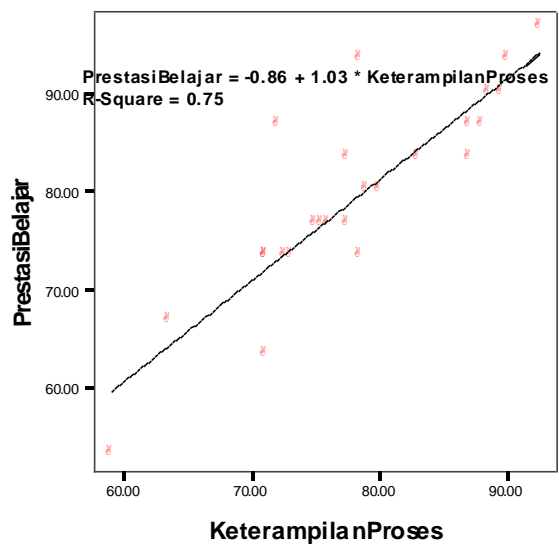

Gambar 2

Grafik Regresi Linear Pengaruh Keterampilan Proses terhadap Prestasi Belajar

Grafik tersebut menunjukkan arah kelakuan data mengarah pada bentuk garis lurus yang bergradien positif. Hal ini berarti keterampilan proses berpengaruh positif terhadap peningkatan prestasi belajar mahasiswa.

Ketuntasan belajar kelas eksperimen dan kelas kontrol dianalisis menggunakan uji One Sample $T$ Test. Untuk kelas eksperimen diperoleh angka signifikan 70,9\% lebih dari $5 \%$, berarti $\mathrm{H}_{0}$ diterima. Dapat disimpulkan bahwa prestasi belajar kelas eksperimen dapat mencapai indikator ketuntasan 70. Tetapi untuk kelas kontrol didapatkan angka signifikan $0 \%<5 \%$, mempunyai arti $H_{0}$ ditolak. Berarti bahwa hasil belajar kelas kontrol tidak dapat mencapai indikator ketuntasan 70 .

Data hasil belajar kelas eksperimen dan kelas kontrol dianalisis untuk diketahui perbedaan hasil belajar di antara kedua kelas tersebut dengan menggunakan uji perbedaan (Independent Sample T Test). Variabel yang diuji adalah prestasi belajar. Data variabel tersebut diperoleh dengan menggunakan alat ukur tes, jadi jenis datanya adalah interval atau rasio.

Sebelum dilakukan uji perbedaan maka dilakukan dulu uji persyaratan data berdistribusi normal. Melihat output, bentuk histogram mendekati kurva normal, garis Q-Q Plot kedudukan titik berada pada posisi tengah. Hal itu menunjukkan secara visual bahwa variable dependen prestasi belajar (Y) berdistribusi normal. Diperkuat dengan uji Kolmogorov-Smirnov terlihat nilai sig $=0.200=20 \%>5 \%$ jadi $\mathrm{Ho}_{\mathrm{O}}$ diterima artinya variable prestasi belajar berdistribusi normal. 
Uji perbedaan di sini dimaksudkan untuk membedakan nilai rata-rata dua variabel dependen yaitu nilai rata-rata prestasi belajar kelas eksperimen dan nilai rata-rata prestasi belajar kelas kontrol. Analisis uji perbedaan dengan memakai Independent Sample $T$ Test antara hasil prestasi belajar kelas eksperimen dan kelas kontrol didapatkan nilai signifikasi 0,001 atau $0,1 \%<5 \%$ berarti kedua sampel mempunyai nilai rata-rata yang berbeda yaitu sebesar 18,75 dari rata-rata nilai prestasi belajar kelas eksperimen $(86,13)$ dan kelas kontrol $(67,38)$. Berarti hasil prestasi belajar kelas eksperimen lebih baik daripada kelas kontrol.

Situasi pembelajaran atau sering disebut sebagai iklim kelas, bersumber pada kondisi yang terjadi ketika proses pembelajaran berjalan, dan lebih lebar lagi kepada interaksi dosen dengan mahasiswa, baik saat di dalam maupun di luar kelas. Belajar akan berlangsung secara efektif dalam situasi yang kondusif. Dalam kondisi yang tenang, mahasiswa termotivasi untuk mengajukan pertanyaan, menyelesaikan tugas, menyampaikan gagasan, dan memberikan respon serta tanpa ada perasaan takut untuk terjadi kesalahan.

Mahasiswa adalah pemeran utama dalam proses pembelajaran karena yang melakukan proses belajar adalah mahasiswa sendiri. Seharusnya, mahasiswa benarbenar menyiapkan mentalnya untuk belajar di perguruan tinggi, mempunyai semangat yang terus membara, sehingga mahasiswa dapat berproses dan menemukan serta meraih tujuan belajarnya. Supaya mahasiswa mampu mencapai tujuan belajarnya dengan cara efektif, ada beberapa hal yang harus dimiliki, yaitu dorongan diri atau motivasi, kesiapan belajar serta tradisi dan keterampilan belajar (Dirjen Dikti Direktorat Pembinaan Tenaga Pendidik dan Ketenagaan Perguruan Tinggi, 2004: 21).

Banyak cara dapat dilakukan, baik oleh pengajar maupun perguruan tinggi untuk dapat menciptakan mental mahasiswa menjadi pembelajar yang termotivasi dan mandiri. Model Pembelajaran Berbasis Proyek Produk Vlog sebagai pendekatan pembelajaran kooperatif dapat mewujudkan kondisi yang kondusif untuk kegiatan pembelajaran. Pada Pembelajaran Berbasis Proyek Produk Vlog mahasiswa dapat berkolaborasi dan bersinergi melalui kelompok dengan benar-benar belajar dan bertanggung jawab untuk tercapainya hasil belajar setiap anggota kelompok. Terdaapat tiga hal penting dalam Pembelajaran Berbasis Proyek Produk Vlog, yaitu 
apresiasi terhadap semua kelompok yang telah melaksanakan tugasnya, tanggung jawab setiap anggota kelompok serta persamaan mendapatkan kesempatan untuk memperoleh hasil. Hal ini ditunjukkan dengan prestasi belajar mahasiswa kelas eksperimen lebih baik dari prestasi belajar mahasiswa kelas kontrol.

Keterampilan proses mahasiswa yang diamati pada kelas eksperimen adalah keterampilan mahasiswa dalam menyelesaikan tugas secara kelompok serta keterampilan proses yang berkaitan dengan memahami dan memaknai materi yang terdapat dalam produk vlog. Hal ini ditampilkan mahasiswa pada saat mempresentasikan hasil kerja kelompok.

\section{KESIMPULAN}

Berdasarkan hasil penelitian dan pembahasannya maka dapat disimpulkan hal- hal sebagai berikut:

1. Pengaruh keterampilan proses sebesar $74,7 \%$ dalam penerapan model Pembelajaran Berbasis Proyek Produk Vlog terhadap prestasi belajar mahasiswa mata kuliah Pendidikan Pancasila Universitas Kristen Petra Surabaya.

2. Model Pembelajaran Berbasis Proyek Produk Vlog lebih efektif dibandingkan model pembelajaran konvensional dalam meningkatkan prestasi belajar mahasiswa pada mata kuliah Pendidikan Pancasila di Universitas Kristen Petra Semarang.

Model Pembelajaran Berbasis Proyek Produk Vlog pada mata kuliah Pendidikan Pancasila baik diimplementasikan dalam proses pembelajaran untuk mengatasi beberapa hal yaitu kurangnya antusias mahasiswa dalam mengikuti perkuliahan, kompetensi mahasiswa yang heterogen, banyaknya pokok bahasan, serta jumlah mahasiswa yang banyak dalam satu kelas.

\section{DAFTAR PUSTAKA}

Arikunto, S. 2002. Prosedur Penelitian Suatu Pendekatan Praktik. Jakarta: Rineka Cipta.

Dirjen Dikti Direktorat Pembinaan Tenaga Pendidik dan Ketenagaan Perguruan Tinggi. (2004). Peningkatan Kualitas Pembelajaran. Jakarta: Dirjen Dikti.

Dryden, G \& Vos, J. (2001). Revolusi cara belajar. Bandung: Mizan Media Utama (MMU).

http://id.wikipedia.org/wiki/Blog_video

Lie, A. (2004). Cooperative learning. Jakarta: PT. Grasindo.

Slavin, R E. 1995. Cooperative learning theory, research, and practice. USA: Allyn \& Bacon.

Sujana, N. (2005). Dasar-dasar Proses Belajar Mangajar. Bandung: Sinar Baru Algensindo. 
Sutisna E, Pemanfaatan Teknologi Informasi dalam Pembelajaran (http://www.bantencerdas.net, Juli 2019).

Syah, Muhibin. (2003). Psikologi belajar. Jakarta: Raja Grafindo Persada. 
Jurnal Edukasi, Volume 5 No.2, Oktober 2019 EISSN. 2598-4187 ISSN. 2443-0455 